Arq. Bras. Med. Vet. Zootec., v.68, n.5, p.1168-1176, 2016

\title{
Experimental acrylonitrile butadiene styrene and polyamide evisceration implant: a rabbit clinical and histopathology study
}

\author{
[Estudo clínico e histopatológico em coelhos eviscerados com utilização de implantes \\ de poliamida e acrilonitrila butadieno estireno] \\ D.C. Gomes Júnior ${ }^{1}$, E.J. Nassar ${ }^{2}$, F.A. Dórea Neto ${ }^{1}$, A.E.Lima ${ }^{1}$, \\ E.F. Martins Filho ${ }^{1}$, A.P. Oriá ${ }^{1 *}$ \\ ${ }^{1}$ Universidade Federal da Bahia - UFBA - Salvador, BA \\ ${ }^{2}$ Universidade de Franca - UNIFRAN - Franca, SP
}

\begin{abstract}
The purpose of this study was to evaluate acrylonitrile butadiene styrene (ABS) and polyamide implants in rabbits submitted to evisceration at the macroscopic and microstructure level and to assess clinical response and histopathological changes as well. For the experimental study implants of $12 \mathrm{~mm}$ diameter were prepared by rapid prototyping, weighed and the outer and inner surfaces evaluated macroscopically and by electron microscopy. In addition, a compression test was performed and ultrastructural damage was then determined. After evisceration of the left eyeball, nine New Zealand rabbits received ABS implants and nine others received polyamide implants. The animals were assessed daily for 15 days after surgery and every seven days until the end of the study (90 days). Histopathological evaluation was performed at 15, 45 and 90 days after surgery. The ABS implants weighed approximately $0.44 \mathrm{~g}$, while the polyamide ones weighed $0.61 \mathrm{~g}$. Scanning electron microscopy demonstrated that the ABS implants had regular-sized, equidistant micropores, while the polyamide ones showed micropores of various sizes. The force required to fracture the ABS implant was 14.39 $\pm 0.60 \mathrm{Mpa}$, while for the polyamide one, it was $16.80 \pm 1.05 \mathrm{Mpa}$. Fifteen days after surgery, we observed centripetal tissue infiltration and scarce inflammatory infiltrate. Implants may be used in the filling of anophthalmic cavities, because they are inert, biocompatible and allow tissue integration.
\end{abstract}

Keywords: rabbits, ocular prosthesis, polymers

\section{RESUMO}

Avaliou-se a macroscopia, a microestrutura, a resposta clínica e histopatológica de implantes de acrilonitrila butadieno estireno (ABS) e poliamida em coelhos submetidos à evisceração. Para o estudo experimental, os implantes foram elaborados por meio de prototipagem rápida, com $12 \mathrm{~mm}$ de diâmetro, pesados e tiveram suas superfícies avaliadas macroscopicamente e por microscopia eletrônica de varredura. Adicionalmente, foi realizado ensaio de compressão para determinar a força necessária para fraturar os implantes. Após a evisceração do olho esquerdo, nove coelhos da raça Nova Zelândia receberam implantes de poliamida e nove outros receberam implantes de ABS. Os animais foram avaliados diariamente nos primeiros 15 dias após a cirurgia e a cada sete dias até o fim do período experimental (90 dias). Avaliação histopatológica foi realizada aos 15, 45 e 90 dias após a cirurgia. Os implantes de ABS pesaram 0,44g, e os de poliamida 0,61g. A microscopia eletrônica de varredura demonstrou que os implantes de ABS eram formados por microporos equidistantes, enquanto os de poliamida apresentavam microporos de vários tamanhos. A força necessária para fraturar os implantes de ABS foi de 14.39 $\pm 0.60 \mathrm{Mpa}$, enquanto para os de poliamida foi de

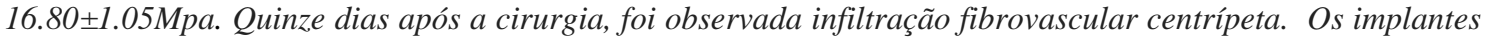
podem ser utilizados para correção de cavidades anoftálmicas por se mostrarem inertes, biocompatíveis e permitirem a infiltração tecidual.

Palavras-chave: coelho, prótese ocular, polímero

Recebido em 18 de agosto de 2015

Aceito em 10 de dezembro de 2015

*Autor para correspondência (corresponding author)

E-mail: arianneoria@ufba.br 


\section{INTRODUCTION}

Patients with congenital or acquired eye disorders may need surgical procedures to remove the eyeball or its contents. Loss of eye causes an aesthetically unacceptable situation. Loss of volume, which is generally replaced with an orbital implant and overlying prosthetic eye, is related. It is extremely important for the artificial eye patient to maintain a natural, normal appearing prosthetic eye (Wang et al., 2012).

Several biomaterials have been used for improving the appearance after surgical procedures such as evisceration, enucleation or exenteration and among these, polymethylmethacrylate, glass, silicon, porous polyethylene and hydroxyapatite (Chuah et al., 2004; Tabatabee et al., 2011; Baino et al., 2014) have been used. With the creation of interconnection channels polymethylmethacrylate implants, tissue infiltration was observed in nonintegrable implants (Oriá et al., 2011). Recently, new articles pointed out that changes in the structure of the implants enable tissue infiltration (Miyashita et al., 2013; Gomes Junior et al., 2015; Oriá et al., 2016)

Despite the diversity of available implants, no ideal one has been defined, therefore, researches to try to find new biomaterials, which fulfill the characteristics of an ideal biomaterial, such as presenting low cost, minimal inflammatory reaction, be capable of sterilization, light and resistance to infection continues (Jordan et al., 2002). The polyamide is considered to be inert and has been used for decades in the form of surgical thread, which causes minimal inflammatory reaction with contact to body tissue (Rahal et al., 1997; Puricelli et al., 2011). Acrylonitrile butadiene styrene already has a wide application in the electronics industry, automobile and household appliances (DíezPascual and Gascón, 2013) but even being a lowcost polymer there are no reports of its use in the health area. With the possibility to manipulate polymers to create a strong, porous structure, the aim of our study was to evaluate spherical acrylonitrile butadiene styrene and polyamide implants in rabbits submitted to evisceration at the macroscopic and microstructure level and to assess clinical response and histopathological changes as well.

\section{MATERIALS AND METHODS}

The research protocols were approved by the Ethics Committee on Animal Use of the School of Veterinary Medicine and Animal Science, Federal University of Bahia, under protocol number $34 / 2013$.

The implants were prepared by the Division of Tridimensional Technology of the Renato Archer Center for Information Technology (Campinas, São Paulo, Brazil). The ABS (ABS P400 ABS Model $^{\circledR}$, Califórnia, USA) spheres were prepared using fusion deposition machining (FDM) technology (Vantage i, Minnesota, USA). The polyamide (Duraform PA ${ }^{\circledR}$, Califórnia, USA) spheres were prepared by selective laser sintering (SLS) technology (Sinterstation ${ }^{\mathrm{TM}} 2000^{\circledR}$, Califórnia, USA). The implants were weighed and the external surfaces were evaluated. In addition, attempts were made to break them between the thumb and forefinger (the pinch test), and the ease with which they could be penetrated with a $25 \times 7$ needle was ascertained. The force required to fracture the implant was determined by a tensile test with crosshead speed of $1 \mathrm{~mm} / \mathrm{min}$, and the fracture site was examined by scanning electron microscopy obtained at $15 \mathrm{kV}$ with several magnifications (Gomes Junior et al., 2015).

After mechanical cleaning with compressed air, implants were individually packaged and sterilized using ethylene oxide (SETE, Bahia, Brazil). To this end, 18 New Zealand rabbits (Oryctolagus cuniculus), males, weighing between 1.9 and $2.4 \mathrm{~kg}$, obtained from a rabbit breeding center (Federal University of Recôncavo of Bahia) were used. All the surgical procedures were conducted under isoflurane (Isoflurane ${ }^{\circledR}$, Cristália, São Paulo, Brazil) general anaesthesia. The left eye of each animal was used for evisceration. After retrobulbar block with 2\% lidocaine (without epinephrine) (Xylestesin ${ }^{\circledR}$, Cristália, São Paulo, Brazil), the evisceration was performed by the same team. After dissection of the conjunctiva and Tenon's capsule, a $360^{\circ}$ keratectomy was performed and four scleral fragments were prepared, each containing a straight extraocular muscle (dorsal, ventral, lateral and medial). Hemostasis was achieved by compression with gauze, and after immersion in saline, the ABS or polyamide implant was inserted (nine animals each). The 
dorsal and ventral fragments were sutured and then the lateral and medial fragments with single 6-0 polypropylene sutures (Prolene ${ }^{\circledR}$, Ethicon, São Paulo, Brazil), so as to cover the implant, followed by suturing Tenon's capsule and conjunctiva with 7-0 polypropylene suture.

Immediately after surgery the rabbits received ketoprofen (Ketofen ${ }^{\circledR}$, Merial, São Paulo, Brazil) at a dose of $1 \mathrm{mg} / \mathrm{kg}$, subcutaneously, and then at regular 24-hour intervals for the first three postoperative days; enrofloxacin (Flotril®, Schering Plough, São Paulo, Brazil) at a dose of $0.025 \mathrm{mg} / \mathrm{kg}$, subcutaneously, single dose. To provide postoperative comfort to the animals, $2 \mathrm{mg} / \mathrm{kg}$ morphine (Dimorf ${ }^{\circledR}$, Cristália, São Paulo, Brazil) was administered subcutaneously at regular 8-hour intervals for the first three postoperative days. Topical antibiotic (Ciloxan ${ }$, Alcon, São Paulo, Brazil) was administered for two weeks every six hours.

Clinical evaluation was performed daily for 15 days and thereafter at intervals of 15 days until the end of the experimental period, always by the same professional. Ocular discharge and chemosis were classified as absent, mild, moderate or severe and the ocular surface was cleaned with gauze and saline after each evaluation to remove secretions. The pain was characterized as present or absent. For this evaluation, the animals were conditioned to allow periocular manipulation during the adjustment period, where after 30 days, the eyelids constrict on handling, but were easily opened with the thumb and index finger to expose the ocular surface. Bleeding, suture dehiscence, and exposure or extrusion of the implants were also assessed.

At each time, 15, 45 and 90 days, three animals from each group were euthanized with an overdose of barbiturate (sodium thiopental) and the left orbit exenterated. The exenterated contents of the left orbit of the rabbits were fixed in $10 \%$ buffered formalin for 48 to $96 \mathrm{~h}$. The capsule surrounding the implant was evaluated macroscopically and the spheres were then sectioned in half with a No. 23 scalpel blade for macroscopic evaluation of tissue integration. Since tissue infiltration could not be confirmed by histopathology because the spheres were rigid and not susceptible to cutting with a microtome, the spheres were subjected to HE staining to assess tissue infiltration better. It should be noted that when spheres were stained with HE and then washed in water, they did not retain the stain. For the histopathological processing, the tissue cover was included in paraffin using routine techniques and stained with hematoxylin and eosin (HE).

\section{RESULTS}

The mean weight of the ABS implants was $0.44 \pm 0.01 \mathrm{~g}$, while the polyamide weighed $0.61 \pm 0.01 \mathrm{~g}$. ABS implants were yellowish, solid, porous and rough while the polyamide ones appeared white, solid, compact and rugged (Figure 1).

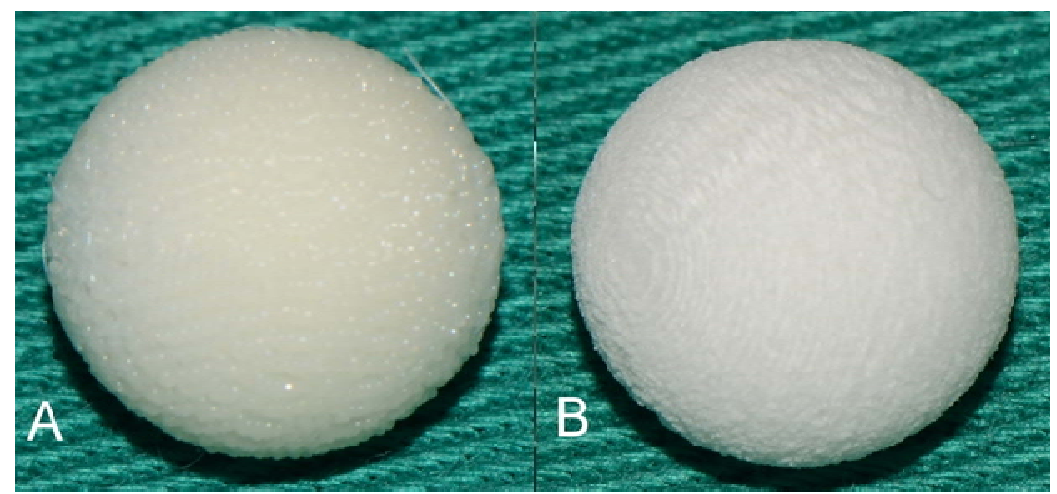

Figure 1. Macrophotographs of the ABS (A) and polyamide (B) implants. Note the irregular appearance of the outer surface of the spheres.

The pinch test and attempt to penetrate the implants with a $25 \times 7$ needle were negative for both implants. The scanning electron microscopy confirmed the findings observed macroscopically in ABS implants, while despite having a compact appearance, polyamide implants proved to be 
porous. The outer surface of the ABS implants was formed by slightly irregular filaments, regularly aligned, parallel and transverse, with the formation of $200-\mu \mathrm{m}$ micropores (Figure 2A). The polyamide implants had numerous irregular-sized microgranules of 15 to $120 \mu \mathrm{m}$ and the formation of micropores of various sizes between 9 and $117 \mu \mathrm{m}$ (Figure 2B). In the compression test, some ABS spheres became deformed and were excluded from the analysis. The mean pressure was $14.39334 \pm 0.59936 \mathrm{Mpa}$ for ABS spheres and
$16.79984 \pm 1.0504 \mathrm{Mpa}$ for polyamide spheres. Scanning electron microscopy of the inner surface showed a filamentous and compact appearance of the ABS filaments as well as an organized structure of $200 \mu \mathrm{m}$ micropores and the fracture area showed disruption of ABS filaments without damage to the rest of the structure (Figure 2B). With regard to the polyamide implant, the inner surface was similar to the outer surface, and in the fracture area, there was disaggregation of microgranules without altering their interaction (Figure 2D).

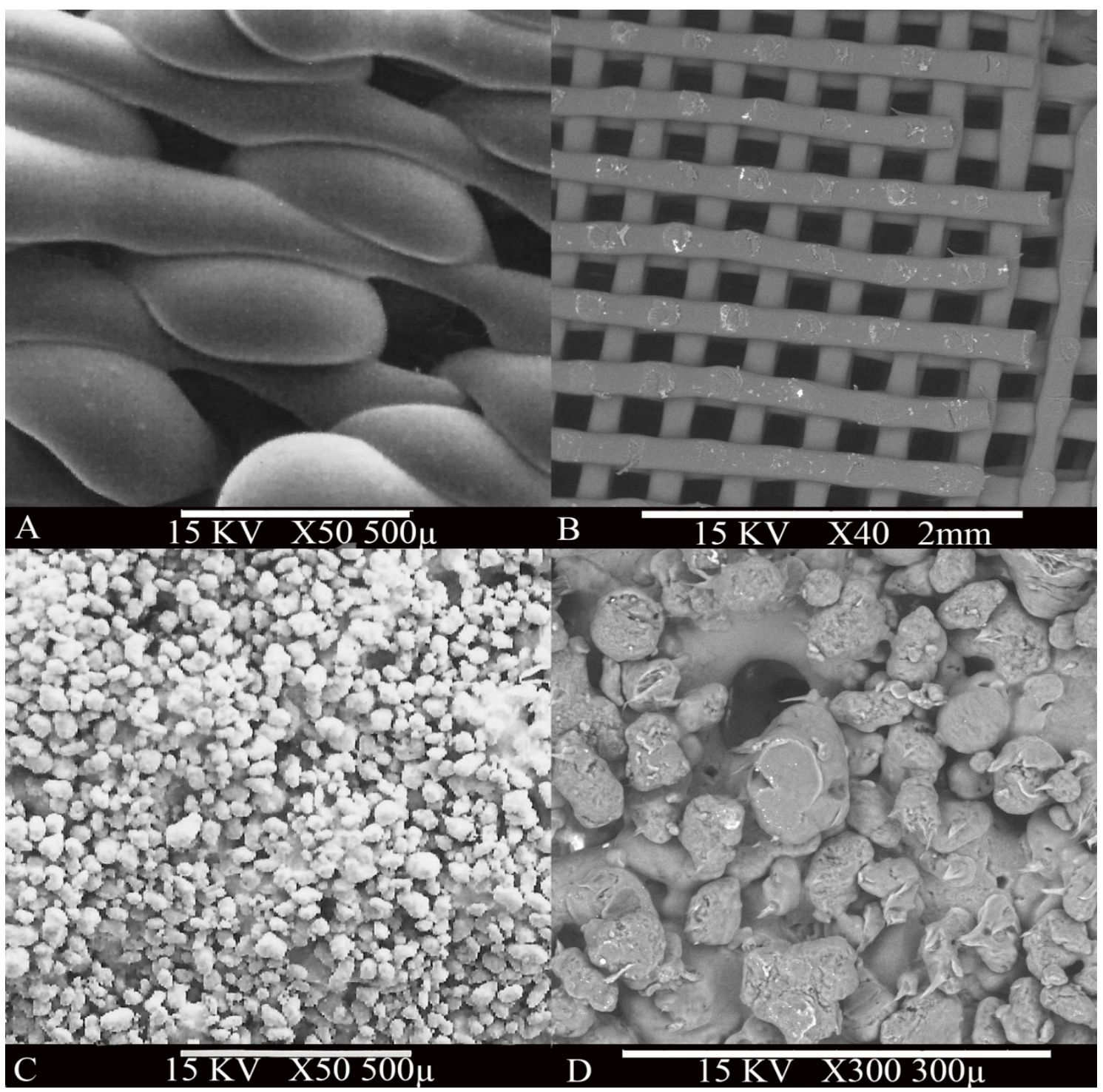

Figure 2. Scanning electron microscopy of the area of the outer and inner (fracture area) surface of ABS $(\mathrm{A}, \mathrm{B})$ and polyamide (C, D) implants. ABS implants (magnification X50 (A) and X40 (B)). Polyamide implants (magnification X50 (C) and X300 (D)). 


\section{Gomes Júnior et al.}

There were no signs of infection, hemorrhage, suture dehiscence, exposure or extrusion of implants. Eye pain was noted in the immediate postoperative period characterized by intense blepharospasm in the first $24 \mathrm{~h}$. After this period, the animals kept eyelids open, but during the following 48h, they showed discomfort on handling, characterized by greater difficulty in opening the eyelids when compared to the nonoperated eye. After this period, the animals did not show discomfort on touching the orbital region and allowed easy opening of the eyelids and exposure of the surgically treated region. Chemosis was observed in all animals in the immediate postoperative period, where it was intense for five days, becoming mild at 15 days and absent in subsequent evaluations. A slight eye discharge of mucoid consistency, whitish, nonpurulent, was observed in the immediate postoperative period and persisted throughout the study. Implant mobility was observed but was not quantified since there was no standard for the species.

In the macroscopic examination, all samples showed a fine capsule strongly adhered to both implants. Part of the capsule could not be removed and remained adhered to the implant surface. When assessing the inner surface of the implants microscopically after sectioning, tissue was observed permeating the micropores. The cell type could not be determined. At 15 days, tissue infiltration was seen heading to the center of the ABS and polyamide implants. At 45 days the tissue partially filled the polyamide spheres and completely filled the ABS spheres. At 90 days, polyamide spheres were completely filled (Figure 3). The filled tissue implants could be more easily visualized after HE staining (Figure 3).

The fragments obtained from the sclera, surrounding the implants in both groups showed similar features upon histopathologic examination. All scleral fragments showed a few inflammatory cells (lymphocytes) 15 days after surgery. At 45 and 90 days, there was no evidence of cells related to inflammatory processes (Figure 4). Evidence of infection or foreign body reaction was not observed in any of the slides.

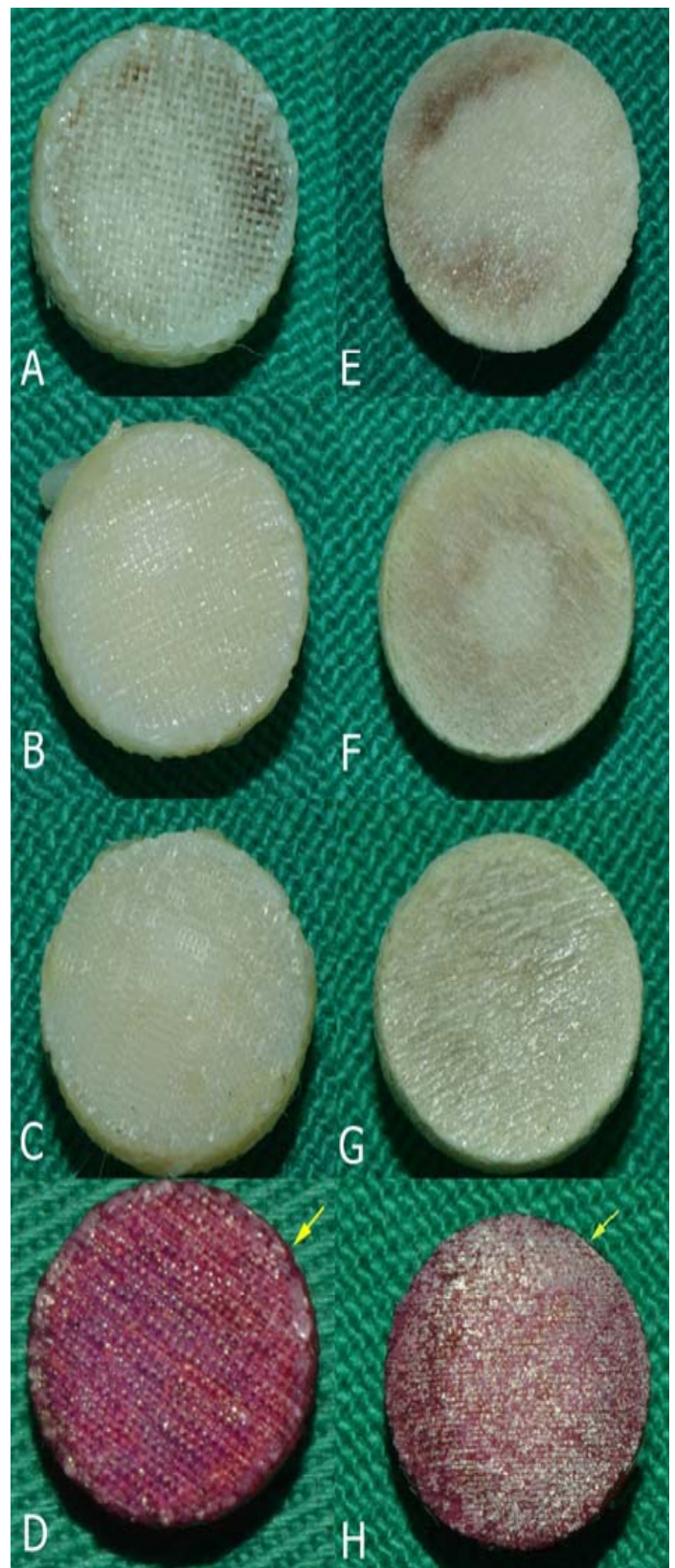

Figure 3. Macrophotographs of ABS (A-D) and polyamide $(\mathrm{E}-\mathrm{H})$ implants after sectioning in half for evaluation of tissue infiltration. Note centripetal tissue infiltration in implants, with darker appearance at 15 days (A and $\mathrm{E}$ ), 45 days (B and $F$ ) and 90 days $(\mathrm{C}$ and $\mathrm{G})$ after surgery. The spheres were stained with HE to observe the tissue infiltration with greater clarity (D and $H$ ). Note the presence of tissue capsule adhered to the implant surface (arrow). 


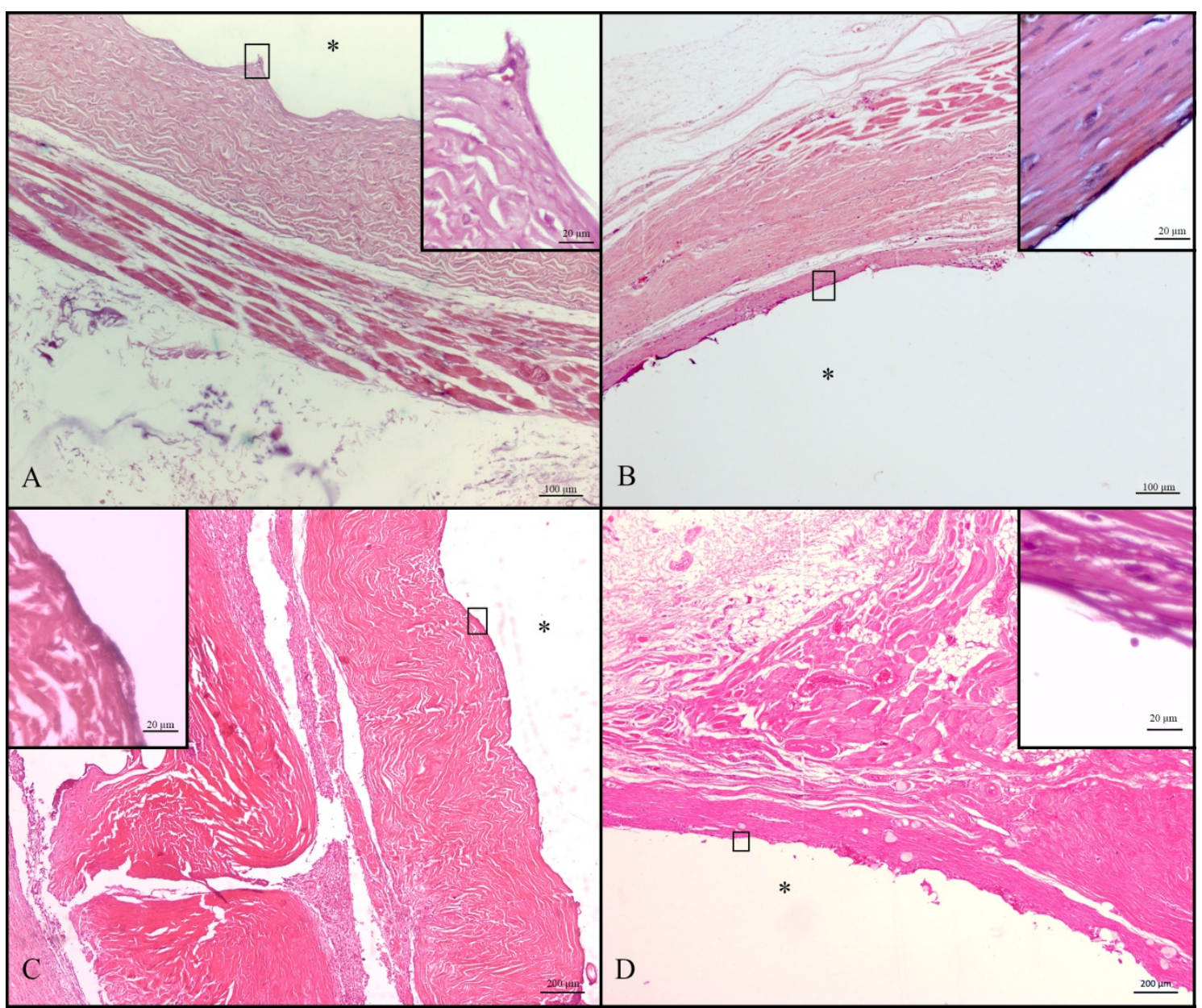

Figure 4. Photomicrographs of the scleral fragments of rabbits after removal of the ABS implant 15 (A) and 90 days after surgery (B) and polyamide implant 15 (C) and 90 days after surgery (D) Note the absence of inflammatory reaction in the area adjacent to the implants $\left(^{*}\right)$ (HE, X50). Magnification (HE, $\mathrm{X} 400)$.

\section{DISCUSSION}

Prototyping techniques are employed in surgical planning, in the manufacture of implants and prosthetics and in the preparation of customized implants (Aherwar et al., 2014). However, to our knowledge, there is only reference to a patented resin (FullCure $720 \circledR$ ) for making orbital implants, which was evaluated in the form of sphere in rabbits subjected to evisceration. The implants proved to be biocompatible but did not integrate (Kormann et al., 2013).

Polymer materials are indispensable in many fields, where they are used, for example, in packages and various medical devices. However, for medical applications, it is necessary to evaluate the possibility of sterilizing the biomaterial and determining its biocompatibility (Sehlinger et al., 2015). According to the manufacturer of polyamide (Duraform $\AA$ ), this compound is certified for use "in vivo." However, for ABS (ABS P400®), there have not been any "in vivo" studies. Besides the question of certification, there is no information in the literature regarding the tissue reaction caused by these materials in the form in which they are designed. Furthermore, the manufacturer indicates that the polyamide should have biological behavior tests conducted after the preparation of a given device for medical use. We were unable to find any published studies on the use of implants produced through rapid prototyping composed of polyamide and $\mathrm{ABS}$, in the medical field. Additionally, there is no information in the literature on the way they are 
designed and on the proposed objective. As main strengths, it should be noted that the materials are easy to purchase and can be produced on an industrial scale.

The first ocular implants were composed of metal or glass which made them heavy and caused discomfort to patients. Therefore, the weight of the implants is a factor that must be considered when choosing a new biomaterial. The polyamide and ABS implants in this study showed weights of 0.60 and $0.44 \mathrm{~g}$, respectively. These values are lower than those of synthetic hydroxyapatite and coral implants weighing 0.62 and $0.79 \mathrm{~g}$, and there is no report in the literature of complications related to the weight of these implants (Jordan et al., 2000).

Non-porous implants such as polymethylmethacrylate are commonly used due to their low cost and ease of sterilization (Yoon et al., 2008), but like double-setting alpha-tricalcium phosphate cement, they do not allow tissue infiltration because of insufficient pores on the surface (Yoon et al., 2008; Baino et al., 2014). In such implants, the creation of interconnecting channels allows for tissue infiltration (Miyashita et al., 2013; Gomes Junior et al., 2015; Oriá et al., 2016). Porosity of the biomaterial appears to exert a greater influence on tissue response obtained. Tissue infiltration occurs in micropores larger than $5 \mu \mathrm{m}$, but macrogranular materials with pores of $150-700 \mu \mathrm{m}$ foster fast fibrovascular growth (Son et al., 2012), which was observed since ABS implants allowed earlier tissue infiltration than did those of polyamide. Considering that the adherence between the capsule and implant and tissue infiltration to the center of the spheres was observed macroscopically, it can be confirmed that the $200 \mu \mathrm{m}$ micropores were sufficient to enable tissue infiltration. The implants composed of the ABS show communication between pores, which allows similar tissue infiltration as porous implants of synthetic hydroxyapatite or porous coral and polyethylene (Yoon et al., 2008; Tabatabaee et al., 2011; Baino et al., 2014).

Like other studies involving orbital implants in rabbits, we did not observe complications such as exposure, extrusion, infection or suture dehiscence (Tabatabaee et al., 2011; Toft et al., 2012; Kormann et al., 2013; Miyashita et al., 2013; Gomes Junior et al., 2015). Eye pain or discomfort was noted in the first three days in the postoperative period and might have been related to surgical manipulation. Chemosis was noted for a few days after surgery and might have been associated with the antiseptic agent employed and surgical manipulation (Miyashita et al., 2013). Eye discharge of whitish mucoid consistency, has already been described by other authors when performing evisceration in rabbits (Toft et al., 2012; Kormann et al., 2013; Miyashita et al., 2013) and it occurred in a discreet manner in the present study.

All foreign material in contact with body tissue causes a tissue reaction. Typically, a fibrovascular capsule is formed to isolate the foreign body from other tissues (Puriceli et al., 2011) and in general, the thicker the capsule, the greater the tissue reaction (Brandão et al., 2013). Polyamide sutures are considered inert, and when placed in contact with the body tissue, a thin capsule is formed around them for the purpose of isolating them from the host tissues (Rahal et al., 1997). Thus, we expected a minimal inflammatory reaction and that the polyamide implant would be surrounded by a thin tissue capsule. Similarly, the reaction to the ABS implant was similar to that with the polyamide implant.

The inflammatory reaction usually lasts a few weeks after surgery and the cellular content of the inflammatory process varies widely according to the biomaterial used. In this study, with both implants, there was sparse mononuclear infiltrate, particularly lymphocytes, which are found in the majority of inflammatory responses to ocular implants. We expected that there would be a minimal inflammatory reaction and that the polyamide implants would be surrounded by a fine tissue capsule in a manner similar to suture, since it is a material considered inert (Rahal et al., 1997). The ABS implants showed a similar tissue reaction as polyamide implants.

In the literature, a more intense inflammatory reaction is noted in the first 15 days, which decreases over time (Miyashita et al., 2013; Gomes Junior et al., 2015) however, both the ABS and polyamide evoked only a minimal inflammatory response by 15 days. At 45 days, there were no inflammatory cells, indicating good acceptance of biomaterials, since 
hydroxyapatite and porous polyethylene implants, considered the best for facial space filling, may show the accumulation of lymphocytes and granulocytes for more than six months after surgery (Toft et al., 2012). If the inflammatory reaction or the capsule showed exuberance at 90 days that would be evidence that the tissue reaction caused by the implant was still in progress and a longer period of evaluation would be necessary. This has been observed with cones of bioglass and bioglass ceramic and double-setting alpha-tricalcium phosphate cement that at 90 days still showed inflammation (Brandão et al., 2013; Gomes Junior et al., 2015).

\section{CONCLUSION}

ABS and polyamide implants are inert and biocompatible and allow tissue integration; they can be used in the filling of anophthalmic cavities.

\section{ACKNOWLEDGMENTS}

We thank the Coordination for the Improvement of Higher Education (CAPES) and the Research Support Foundation of the State of Bahia (FAPESB DCR0019/2015) for financial support.

\section{REFERENCES}

AHERWAR, A.; SINGH, A.; PATNAIK, A. A review paper on rapid prototyping and rapid tooling techniques for fabrication of prosthetic socket. In: BARTOLO, P.J.; LEMOS A.C.S.; PEREIRA, A.M.H. et al. (Eds). High value manufacturing: advanced research in virtual and rapid prototyping. London: Taylor \& Francis Group, 2014. p.45-353.

BAINO, F.; PERERO, S.; FERRARIS, S. et al. Biomaterials for orbital implants and ocular prostheses: overview and future prospects. Acta Biomater., v.10, p.1064-1088, 2014.

BRANDÃO, S.M.; SCHELLINI, A.S.; PADOVANI, C.R. et al. Análise da biocompatibilidade de cones de biovidro e biovitrocerâmico (Biosilicatoß) em cavidade eviscerada de coelho. Rev. Bras. Oftalmol., v.72, p.21-25, 2013.
CHUAH, C.T.; CHEE, S.P.; FONG, K.S. et al. Integrated hydroxyapatite implant and nonintegrated implants in enucleated Asian patients. Ann. Acad. Med. Singapore, v.33, p.477-483, 2004.

DÍEZ-PASCUAL, A.M.; GASCÓN, D. Carbon nanotube buckypaper reinforced acrylonitrile-butadiene-styrene composites for electronic applications. ACS Appl. Mater. Interfaces, v.5, p.1210-1219, 2013.

GOMES JUNIOR, D.C.; ORIÁ, A.P.; DÓREA NETO, F.A. et al. Double-setting alphatricalcium phosphate cement provided with interconection channels in rabbits after enucleation: A potential implant for the anophthalmic socket. Arq. Bras. Med. Vet. Zootec, v.67, p.119-124, 2015.

JORDAN, D.R.; MAWN, L.A.; BROWNSTEIN, S. et al. The bioceramic orbital implant: A new generation of porous implants. Ophthal. Plast. Reconstr. Surg., v.16, p.347-355, 2000.

JORDAN, D.R.; BROWNSTEIN, S.; GILBERG, $\mathrm{S}$. et al. Investigation of bioresorbable orbital implant. Ophthal. Plast. Reconstr. Surg., v.18, p.342-348, 2002.

KORMANN, R.B.; MOREIRA, H.; CRESCENTE, G.; FOGGIATTO, J.A. Estudo experimental da biocompatibilidade de novo material para implante orbitário. Arq. Bras. Oftal., v.76, p.141-146, 2013.

MIYASHITA, D.; CHAHUD, F.; BARROS da SILVA, G.E. et al. Tissue ingrowth into perforated polymethylmethacrylate orbital implants: An experimental study. Ophthal. Plast. Reconstr. Surg., v.29, p.160-163, 2013.

ORIÁ, A.P.; COSTA NETO, J.M.; LIMA, A.E.S. et al. Comportamento do polimetilmetacrilato munido com canais de interconexão como implantes orbitários em coelhos. In: CONGRESSO BRASILEIRO DA ANCLIVEPA, 32., 2011, Goiânia. Anais... Goiânia: ANCLIVEPA, 2011. (Resumo expandido).

ORIÁ, A.P.; SOUZA, M.R.; DÓREA NETO, F.A. et al. Polymethylmethacrylate orbital implants with interconnecting channels. A retrospective study following enucleation in dogs and cats. Vet. Ophthal., v.19, n.2, p.102-9, 2016. 


\section{Gomes Júnior et al.}

RAHAL, S.C.; ROCHA, N.S.; FIGUEIREDO, L.A.; IAMAGUTI, P. Estudo comparativo da reações teciduais produzidas pela "linha de pesca" (poliamida) e fio de náilon cirúrgico. Cienc. Rural, v.28, p.89-93, 1997.

SEHLINGER, A.; OCHSENREITHER, K.; BARTNICK, N.; MEIER MAR. Potentially biocompatible polyacrylamides derived by the Ugi four-component reaction. Eur. Polym. J., v.65, p.313-324, 2015.

SON, J.; KIM, C.; YANG, J. Comparison of experimental porous silicone implants and porous silicone implants. Graefs Arch. Clin. Exper. Ophthalmol., v.250, p.879-885, 2012.

TABATABAEE, Z; MAZLOUMI, M.; RAJABI, M.T. et al. Comparison of the exposure rate of wrapped hydroxyapatite (Bio-eye) versus unwrapped porous polyethylene (Medpor) orbital implants in enucleated patients. Ophthal. Plast. Reconstr. Surg., v.27, p.114-118, 2011.
TOFT, P.B.; RASMUSSEN, M.L.; PRAUSE, J.U. One-stage explant-implant procedure of exposed porous orbital implants. Acta Ophthalmol., v.90, p.210-214, 2012.

PURICELLI, E.; NÁCUL, A.M.; PONZONI, D. et al. Implante intramuscular de polimetilmetacrilato (PMMA) 30\%, associado a veículo não-proteico: estudo experimental em ratos. Rev. Bras. Cir. Plast., v.26, p.385-389, 2011.

WANG, J.; ZHANG, H.; CHEN, W.; LI, G. The psychosocial benefits of secondary hydroxyapatite orbital implant insertion and prosthesis wearing for patients with anophthalmia Ophthal. Plast. Reconstr. Surg., v.28, p.324-327, 2012

YOON, J.S.; LEW, H.; KIM, S.J.; LEE, S.Y. Exposure rate of hydroxyapatite orbital implants a 15-year experience of 802 cases. Ophthalmology, v.115, p.566-572, 2008. 